\title{
A RESERVA INDÍGENA RAPOSA SERRA DO SOL: DIREITO AO DESENVOLVIMENTO SUSTENTÁVEL DOS INDÍGENAS VERSUS DIREITO DE EXPLORAÇÃO DA ATIVIDADE ECONÔMICA DOS RIZICULTORES.
}

\section{THE INDIGENOUS RESERVE FOX SUN SERRA: RIGHT TO SUSTAINABLE DEVELOPMENT OF INDIGENOUS VERSUS ACTIVITY OF EXPLORATION RIGHT OF ECONOMIC RICE FARMERS.}

\author{
${ }^{1}$ Elaine Freitas Fernandes \\ Ferreira
}

\section{RESUMO}

O estudo objetiva demonstrar que os povos indígenas sofrem com invasões a suas terras, intensificadas pela cobiça do poder econômico e pela omissão do Estado. Em um certo período, os indígenas asseguravam as fronteiras do território brasileiro em regiões mais remotas, locais que os brancos não estavam dispostos a enfrentar. Uma vez assegurado o território e facilitado o acesso passou haver exploração econômica, em terras indígenas. $\mathrm{O}$ mesmo Estado que precisou dos índios para fortalecer e consolidar as fronteiras incentivou, e posteriormente, até concedeu títulos de propriedade para "brancos" em terras indígenas, dizimando inúmeras comunidades, o que ocorreu até meados do século XX. A Terra Indígena Raposa Serra do Sol, embora tenha seu direito à demarcação reconhecida pelo Supremo Tribunal Federal, sofreu com maciça exploração da rizicultura. Verificou-se que, após o término da monocultura do arroz, não houve diminuição do desempenho econômico no Estado de Roraima que teve no produto interno bruto o maior crescimento em dez anos. O crescimento em volume do PIB de Roraima no ano de 2010 foi da ordem de 9,6\%, ocupando a nona posição no ranking nacional e a quinta posição na Região Norte.

Palavras-chave: Reserva indígena raposa serra do sol, Direito ao desenvolvimento sustentável, Exploração da atividade econômica pelos rizicultores

\section{ABSTRACT}

The study aims to demonstrate that indigenous peoples suffer from invasions of their land, intensified by the greed of economic power and the State's failure. At one time, the natives assured the borders of Brazil in remote areas, places that the whites were not willing to face. Once secured territory and facilitated access be passed economic exploitation in indigenous lands. The same state that needed the Indians to strengthen and consolidate the borders encouraged, and thereafter until granted land titles to "white" on indigenous lands, decimating many communities, which occurred until the mid-twentieth century. The Raposa Serra do Sol, although their right to demarcation recognized by the Supreme Court, suffered from massive exploitation of the rice culture, it was found that, after completion of the rice monoculture, there was no decline in economic performance in the State of Roraima whick took in gross domestic product the highest growth in a decade. The growth in Roraima GDP volume in 2010 was approximately 9.6\%, ranking ninth in the national ranking and the fifth position in the North.

Keywords: Indigenous reserve fox sun serra, Right to sustainable development, Exploration of economic activity by rice farmers

\footnotetext{
${ }^{1}$ Mestre em Direito, Políticas Públicas e Desenvolvimento Regional, pelo Centro Universitário do Pará -CESUPA, Belém, Pará, Brasil. Advogada;Delegada adjunta da CAA-Caixa de Assistência dos Advogados-Pará,(Brasil) Email: tutortreinamento@gmeial.com
} 


\section{INTRODUÇÃO}

A questão que pretendo responder no presente artigo, é se a Reserva Indígena Raposa Serra Do Sol tem um Direito Ao Desenvolvimento Sustentável em contraponto ao Direito de Exploração da Atividade Econômica dos Rizicultores, e se o fim da exploração da atividade econômica através da rizicultura causou diminuição do Produto Interno Bruto (PIB) no Estado de Roraima, afetando a economia local.

Para tanto, será necessário entender a formação da Terra Indígena Raposa Serra do Sol (TIRSS) e o motivo pelo qual sua demarcação, decorrente da decisão do Supremo Tribunal Federal (STF) trata-se de um caso emblemático para a história da luta pelos direitos indígenas em nosso país.

O processo demarcatório da TIRSS, teve início em 1977 e foi concluído em 2005, manifestando a abrangência e a complexidade dessas disputas por terras. Os conflitos na região e o próprio processo de demarcação geraram uma série de ações judiciais, visto que ocorreu uma intensa divisão de posições. De um lado aqueles que se mostram contrários à demarcação. De outro, aqueles que argumentam a favor da homologação da reserva nos moldes do decreto presidencial.

A resistência por parte dos grupos oposicionistas à demarcação, ao se recusarem a cumprirem ordens de desocupação da reserva e ao buscar constantemente decisões judiciais que mantenham sua posse sobre a área, constituiu grave ameaça à determinante homologação da reserva e, por conseguinte, o desrespeito à concretização do direito constitucional dos índios à posse das terras que tradicionalmente ocupam.

O STF buscou solucionar um antigo conflito existente na região entre os indígenas e os rizicultores, no qual aqueles buscavam manter seus métodos tradicionais na utilização dos recursos naturais e, estes, a exploração econômica, ambos buscando a sobrevivência.

No caso em tela, além das divergências em volta das fases do processo administrativo de demarcação da terra indígena, ainda a existência de uma discussão mais profunda que revela a desarmonia entre valores, princípios e objetivos que rodeiam a atual sociedade brasileira. Esse debate assenta a possibilidade de um equilibrio entre o respeito à diversidade e a prática de políticas que objetivam o desenvolvimento econômico do país.

Diante desse cenário, iniciou-se um extenso processo para o reconhecimento da posse originária e a demarcação oficial dessa área para o uso exclusivo dos indígenas.

Será observado através da exploração da atividade econômica praticada pelos rizicultores em contraponto ao direito ao desenvolvimento sustentável dos indígenas como um 
elemento primordial ao reconhecimento de seus métodos tradicionais de utilização dos recursos naturais para sua sobrevivência.

A monocultura do arroz foi introduzida través de títulos de terra concedidos pelo próprio Estado, na Terra Indígena Raposa Serra do Sol, provocando um duro embate entre os donos originários da terra e entre os representantes poder econômico.

Por fim, demonstrarei como se encontra a economia no estado de Roraima após a demarcação da TIRSS, demonstrando que sempre foi um tema polêmico a demarcação de terras indígenas no Brasil.

A proposta deste trabalho não é simplesmente detalhar a história de um conflito local, mas, demonstrar o duplo movimento, de expor tanto o modo de viver e sua relação com a terra pelos índios quanto as dos arrozeiros de modo a afrontar as intervenções, os distintos conhecimentos e gerenciamentos tecnológicos que cada um promovia na Raposa Serra do Sol, no primeiro, a pecuária extensiva, no segundo, a rizicultura de alta performance. Abraçar a estratégia etnográfica de seguir a trilha do gado e a trilha do arroz permite demonstrar o choque de saberes, conceitos e lógicas diferenciados na ocupação da Raposa Serra do Sol.

De um lado, o caminho do gado na terra indígena nos leva a relações de organizações sustentadas por meio de desenvolvimento sustentável. De outro lado, o caminho do arroz expõe o investimento de capital na região, que ocuparam o território com maquinários, sementes híbridas e produtos químicos.

\section{A FORMAÇÃO ECONÔMICA DO TERRITÓRIO QUE DEU ORIGEM A TERRA INDÍGENA RAPOSA SERRA DO SOL}

De acordo com Nádia Farage e Paulo Santilli (2009), o vale do Rio Branco foi objeto de um processo peculiar de ocupação colonial na segunda metade do século XVIII, em virtude de sua condição de fronteira portuguesa com as possessões da Espanha e dos Países Baixos na Guiana.

Conforme explicitam os autores, essa área marginal no quadro da economia da Amazônia é também periférica em relação às demais regiões de colonização portuguesa na América. O Rio Branco ao lado do alto Rio Negro, foi uma das últimas áreas a serem alcançadas pelo avanço da colonização portuguesa na Amazônia. Tal ocupação tardia deveu- se, basicamente, ao fato de que a área não oferecia nenhum produto de exploração fácil e rentável para o mercado colonial. (Nádia Farage e Paulo Santilli 2009 p. 21). 
O baixo Rio Branco foi, objeto de exploração extrativista no período colonial, ali plantando-se cacau, item importante das exportações na Amazônia, e, em menor grau, baunilha e outros produtos de extração. Porém, de acordo com os autores, o baixo Rio Branco certamente conforma área bastante diferenciada dos campos e serras no extremo norte do que é o estado de Roraima. Nesta ultima área em particular, os cronistas setecentistas relatam a ocorrência de produtos comerciáveis no contexto da economia colonial amazônica, como a baunilha, madeiras ou resinas, mas tal extração pôde ser adiada em favor da exploração de outras áreas de mais fácil acesso na Amazônia.

Farage (1991 pág. 55) informa que:

"O apresamento clandestino de escravos índios atingiu a região de Rio Branco no início do século XVIII e, de forma oficial, a partir dos anos 30 daquele século. É, entretanto, sob a égide do Tratado de Madrid, que dispunha sobre a demarcação das fronteiras coloniais luso-espanholas, que a ocupação do Vale do Rio Branco viria a se tornar um imperativo de ordem político-estratégica.

O tratado de Madrid, em 1750 foi a primeira tentativa, desde Tordesilhas, de delimitação de fronteiras coloniais luso espanholas, guiava-se, exatamente, pelo princípio da posse de fato, estabelecendo que cada parte deteria os territórios até então ocupados e povoados. Assim, durante o ministério pombalino, a tônica foi a de povoar "todas as terras possíveis", contando com a população indígena como base de uma sociedade colonial.( FARAGE \& SANTILLI, 2009).

Ainda mais exemplar é o Parecer do Conselho Ultramarino de 20.12.1965, que afirmava que os "Gentios erão as muralhas dos Certoens" (FARAGE, 1991 p. 41-42).

Nota-se, assim, que a ocupação portuguesa no Rio Branco não foi feita por colonos brancos, mas, ao contrario, o inicio de uma ocupação efetiva da região na década de 70 do século XVIII foi basicamente desempenhada pelo Estado, consistindo na construção de uma fortaleza, o Forte de São Joaquim, e na formação de aldeamentos indígenas sob a jurisdição daquela guarnição militar.( FARAGE \& SANTILLI, 2009 p.23).

Entre os anos de 1777 e 1780 foram constituídos no Rio Branco cinco aldeamentos, que somaram 1019 habitantes; entre 1784 e 1789, foram estabelecidos outros cinco aldeamentos seculares, que chegaram a contabilizar 1051 habitantes, atingindo os Wapishana, Paraviana, Sapará, Parauna e, em menor grau, os Macuxi e os Waycá (Ingarikó), habitantes das serras mais distantes. (FARAGE SANTILLI \&, 2009, p.23) 
Em 1780, de acordo com FARAGE \& SANTILLI (2009) ocorreu uma revolta generalizada da população indígena aldeada; os aldeamentos foram reorganizados em 1784 até nova revolta, em 1790. Após esta ultima revolta, quando os aldeamentos foram desmantelados e a população remanescente capturada foi dispersa por aldeamentos em diferentes pontos da Amazônia, o Estado não voltaria a investir, politicamente, no aldeamento de índios como forma de ocupação da área. O projeto de estabelecer aldeamentos indígenas e guarnições militares, como forma de preservação territorial, continuou, porém, presente, ao menos retoricamente, no império. Da experiência colonial, restaria na região uma forma incipiente de exploração econômica, representada pela pecuária.

Segundo FARAGE (1991), habitantes de uma fronteira, fruto de disputa colonial, os povos indígenas na região também foram afetados pelo processo colonizatório holandês da Guiana, no mesmo período que a colonização portuguesa se iniciava. Os holandeses atingiram a região através de uma rede extensa e multilateral de trocas de manufaturados por escravos índios, que envolvia povos indígenas desde o baixo rio Essequibo até o vale do Rio Branco. A inserção dos holandeses nesta rede de trocas thes valeu a aliança política com os índios, que, mais tarde, seria reivindicada pela Inglaterra como título de domínio territorial.

O litígio de fronteiras entre Brasil e Inglaterra teve início na década de trinta do século XIX, com a instalação da missão anglicana de Pirara, nos campos entre os rios de mesmo nome e o rio Rupunini, fronteira ainda indefinida entre a Guiana Inglesa e o Império do Brasil. O governo brasileiro viria a considerar que a missão se encontrava em seus domínios e, em 1839, enviaria à região um destacamento militar para desalojá-la, sob a acusação de haver "alienado" ao Brasil quinhentos índios Macuxi e de ter instruído na língua e na religião inglesas. (FARAGE \& SANTILLI 2009).

Propunha R. H. Schomburgk que a linha divisória entre Inglaterra e o Império brasileiro seguisse a margem direita do rio Tacutu, das suas nascentes até a junção do rio Surumu, prosseguindo deste ponto às nascentes do rio Cotingo. A Inglaterra encampou a linha Schomburgk $^{1}$, dando curso ao litígio com o Brasil. Em 1842, um acordo provisório entre os

\footnotetext{
1 Schomburgk nasceu em Freyburg, cidade às margens do rio Unstrut, na Saxônia-Anhalt, filho de um pastor protestante. Em 1830, Schomburgk partiu para a ilha de Anegada, uma das ilhas Virgens, famosa por seus naufrágios de navios. Cuidou da ilha por conta própria e enviou à Royal Geographical Society, em Londres, um relatório que criou tamanha impressão que, em 1835, a ele foi confiado o comando de uma expedição à então Guiana Inglesa. Ele cumpriu sua missão (1835-1839) com grande êxito, e incidentalmente descobriu em 1837 uma planta aquática que posteriormente denominou Vitória-régia. Em 1841 voltou à Guiana, desta vez como oficial do Governo Britânico para mapear e fixar suas fronteiras. O resultado foi uma fronteira provisória entra a Guiana e a Venezuela, conhecida como a "Linha Schomburgk", assim como a fronteira com
} 
a colônia neerlandesa do Suriname. Ele veementemente aconselhou a regulamentação da fronteira com o Brasil, já que alegou ter visto escravidão de índios locais - muitos dos quais já extintos - por brasileiros. dois países veio a neutralizar o território disputado. A pendência só seria solucionada em 1904, por arbitragem submetida ao rei da Itália, resultando na linha fronteiriça que, ainda hoje, separa o estado de Roraima, Brasil e a República da Guiana ( FARAGE \& SANTILLI, 2009, p.24).

Nota-se, assim, que, atualizando as balizas da contenda colonial setecentista, o estabelecimento da fronteira trazia, novamente, à cena o peso político-estratégico dos povos indígenas. Em consequiência, os povos indígenas compuseram elemento pivotal na alegação das partes litigantes, ambas declarando as relações historicamente estabelecidas com eles na área, em defesa de suas pretensões territoriais. A linha Schomburgk, não vigorou e o Brasil manteve a maior parte do território disputado, que corresponde, em larga medida, à área atual da Terra Indígena Raposa Serra do Sol (FARAGE \& SANTILLI 2009 pag. 24).

\subsection{Pecuária}

De acordo com FARAGE \& SANTILLI (2009), citando P. Riviére, (1972), os estudos permitem afirmar que, subsistemas econômicos baseados na pecuária foi, tradicionalmente, uma atividade desenvolvida em regiões economicamente marginais, com dificuldade de acesso a mercados, pois possibilitava o suprimento interno e, assim, a relativa independência de que necessitam regiões isoladas.

Esta linha explicativa bem se aplica ao início da pecuária em Roraima em fins do século XVIII: além de uma extração de lucratividade duvidosa, eram os campos que imediatamente se ofereciam à vista, e para eles os cronistas voltar-se-iam com insistência, realçando sua potencialidade para a criação de gado. (FARAGE \& SANTILLI, 2009, p.24).

A pecuária não foi uma atividade empreendida por colonos civis. Ao contrário, sua implementação foi iniciativa oficial, visando, justamente, integrar a região do Rio Branco ao mercado interno colonial. Tal iniciativa partiu do Governo da Capitania de São José do Rio Negro durante a administração de Manuel da Gama Lobo D'Almada, que ali introduziu as primeiras cabeças de gado em 1787 (FARAGE \& SANTILLI, 2009, p.25).Vigorou nesse momento, fazendas com gigantescas extensões de terras, cuja propriedade era do Estado. Vejamos:

Posteriormente, suas exploraçõesnessa região geraria um conflito diplomático que seria denominado Questão do Pirara, noqualoBrasilcedeu dois terços do território disputado. Fonte: http://pt.wikipedia.org/wiki/Robert Hermann Schomburgk acessado em 24 de maio de 2015. 
(...) Tal tipo de propriedade certamente não configura uma peculiaridade única de Roraima, tendo também ocorrido em outros pontos da colônia. No entanto, sua singularidade reside no fato de que, em Roraima, tratava-se de terras indígenas que, em parte, foram assim reconhecidas posteriormente.

As fazendas régias, ou como foram conhecidas posteriormente, as fazendas do rio Branco, não foram medidas ou demarcadas durante todo o século XIX, Havia, no entanto, o reconhecimento tácito de sua existência e, é essencial notar, a propriedade do Estado sobre tais terras jamais foi contestada.

na segunda metade do século XIX, o quadro da disputa de fronteiras com a Inglaterra, o estado Brasileiro veio a se interessar em descrever os limites das fazendas e determina-lhes as origens.

Verifica-se, portanto, que até o final do século XIX, o estado era proprietário da imensa maioria das terras da região. Datam, das duas últimas décadas do século XIX as primeiras referências ao estabelecimento significativo de civis na área, o que viria a afetar, profundamente, a situação da terras de propriedade do Estado na região.

O esbulho das terras das fazendas nacionais iniciaria, formalmente, na década de 1980 do século XX, com o arrendamento das fazendas a poderosos empresários amazonenses. Ficaram reservadas porém, as fronteiras e outras áreas para fins militares, (FARAGE \& SANTILLI, 2009, pags. 27-28).

As fazendas de particulares proliferaram-se às expensas do patrimônio nacional, além das terras, o roubo de gado pertencente ao estado constituiu prática corriqueira entre os posseiros, formando e engrossando rebanhos particulares em detrimento do estatal (FARAGE \& SANTILLI, 2009, pag. 28).

Em 1927, a comissão de Inspeção de Fronteiras, instituída pelo Ministério da Guerra, percorreu, sob o comando do General Rondon, o curso dos rios Tacutu, Surumu, Contigo e Mau (ou Ireng), tendo encontrado suas margens povoadas por aldeias Macuxi, Ingaricó, e, ao sul, Wapixana, com uma população estimada, em pelo menos, 2.000 indivíduos (FARAGE \& SANTILLI, 2009 p. 30).

As aldeias Macuxi conservaram sua territorialidade ao longo do século XX, o que, teve reconhecimento formal, por parte do Estado brasileiro, com a homologação da TI Raposa Serra do Sol em 2005.

Cálculos recentes do Conselho Indígena de Roraima (CIR $)^{2}$ estimam o rebanho na Raposa Serra do Sol em 37 mil cabeças de gado na Raposa Serra do Sol, onde todas as famílias são responsáveis pelo cuidado, e o manejo fica a cargo de uma ou mais família com decisão de todos os membros da comunidade, ficando o papel do tuxaua de coordenar as

\footnotetext{
2 CIR - CONSELHO INDÍGENA DE RORAIMA. Nota do Conselho Indígena de Roraima sobre a matéria da Folha de Boa Vista.Disponível em: http://www.cir.org.br/index.php/component/k2/item/244-nota-do-conselho-ind\%C3\%ADgena-de- roraima-sobre-a-mat\%C3\%A9ia-dafolha-de-boa-vista. Acessado em 14/04/2015.
} 
atividades gerais, mas as deliberações são feitas pela comunidade, portanto o tuxaua não manda na comunidade. É infundada a informação de que tem lideranças com mais de 3000 bovinos, pois em Roraima tem apenas uma comunidade com 2000 bovinos.

$\mathrm{O}$ gado existente nas comunidades e terras indígenas coordenados pelo CIR tem uma avaliação anual, e a cada cinco anos cada comunidade tem obrigação de fazer repasse de gado para outra comunidade na quantidade do projeto, que é 50 matrizes e 02 touros.

Em geral, o gado bovino é patrimônio comunitário, assim como a terra e outros, todos têm direitos e deveres na ordem coletiva. Todas as indenizações de boa-fé é usufruto exclusivo das comunidades indígenas, não ficando apenas para interesse particular, por isso o tuxaua ou outro membro não tem direito de se beneficiar de forma individual. E caso houver qualquer liderança, seja tuxaua ou não envolvido em atividades ilegais é punido imediatamente com a perda do cargo e denunciado para órgãos competentes de fiscalização e proteção. (CIR, 2013).

\subsection{Rizicultura}

O plantio do arroz em Roraima teve início na colonização do antigo território de Roraima em 1944, com a chegada de agricultores maranhenses. No entanto, a exploração da cultura do arroz em escala comercial, foi concretizada a partir de 1977, quando migrantes oriundos da região sul do Brasil deram início a lavoura mecanizada nas áreas de cerrado, com a utilização de insumos agrícolas no preparo do solo à colheita. A produção do arroz em Roraima apresentou um crescimento significativo até 1981, mais pela extensão da área do que por acréscimo na produtividade. CORDEIRO (2001 Apud Sakazaki, R. T. et al 2008, p. 70).

Segundo dados da Secretaria de Planejamento (SEPLAN/RR, 1980, p.74), até 1977 a área cultivada de arroz totalizava 6.330 hectares e as colônias agrícolas eram marcadas pela "agricultura de subsistência, itinerante e rudimentar" (Governo do Estado de Roraima, 2003, p. 36).

À época do julgamento no STF, o cultivo do arroz irrigado era praticado por 30 produtores que cultivavam, cada um, 600 hectares por ano, sendo a produção das maiores delas - algumas das quais dentro da Raposa Serra do Sol -, em torno de 1.000 hectares por ano (SAKAZAKI et al., 2008. p. 70).

Nesse espaço de 30 anos, entre o ano de 1977 e o julgamento que define a desintrusão dos rizicultores da Raposa Serra do Sol, há uma crescente preocupação em 
"racionalizar" a produção do arroz, estimulando a agricultura tida como comercial, não itinerante e moderna.

A finalidade era potencializar ao máximo a produtividade da cultura do arroz. desenvolvendo ferramentas para alcançar o domínio total de determinado ambiente, que precisaria se tornar improdutivo para todo o tipo de agricultura que não a do arroz.

De acordo com SAZAKI (2008), os arrozeiros, somente, se fixaram em Roraima, no momento em que multiplicaram as empresas e órgãos locais que transportavam consigo um regime de saber que os acoplava a empresas estrangeiras fornecedoras de insumos para a rizicultura. Ressalte-se, que, as empresas de beneficiamento de arroz eram individuais ou limitadas, o que sugeria que esses atrelamentos não aconteciam por meio de capital estrangeiro investido diretamente nas empresas, ou por meio de exportação, já que o arroz de Roraima não era exportado, mas escoado para o mercado de Manaus e Santarém.

A partir de 1982 a produtividade de arroz e as áreas cultivadas tiveram uma redução drástica, cerca de $70 \%$, em virtude de estiagens prolongadas na fase de florescimento da cultura, aparecimento de doenças e sementes de péssima qualidade apresentando baixo poder de germinação, forçando os produtores a mudarem de área e melhorar as tecnologias utilizadas, buscando novas técnicas de cultivo e a adoção do uso de cultivares melhoradas. (SAKAZAKI et. al., 2008, p. 70).

Como parte dos esforços para racionalizar o sistema de produção envolvia o deslocamento dos produtores para áreas mais apropriadas, VIANNA (2015) informa que o governo federal instaurou o Programa de Aproveitamento Racional das Várzeas Irrigáveis (PROVÁRZEAS). A coordenação técnica estava a cargo da Empresa Brasileira de Assistência Técnica e Extensão Rural (EMBRATER), atual EMBRAPA. Vejamos, (CORDEIRO, 2004, pag.):

\footnotetext{
O advento do PROVÁRZEA em 1981/82 motivou o aproveitamento das várzeas existentes em Roraima, cerca de 160.000 hectares em potencial. Esses ecossistemas, principalmente os localizados na região de lavrados (cerrados), apresentam topografia plana e facilidades para mecanização agrícola e irrigação. A opção de ocupação dessas várzeas foi como cultivo do arroz irrigado mecanizado, aproveitando a experiência com a cultura de agricultores migrantes do sul do país.
}

O avanço de produtividade é reflexo dessa migração e do aumento das áreas de cultivo, o Ministro Relator Carlos Ayres Britto no julgamento da demarcação da TIRSS denominou de "inescondível esbulho" (BRITTO, 2009, p. 213), parte do processo de racionalização e da busca por condições ideais para se atingir os ambientes controlados. $\mathrm{O}$ modelo gaúcho do agronegócio atinge com força a Terra Indígena Raposa Serra do Sol, na 
medida em que se associa, direta ou indiretamente, a instituições que envolvem parcerias como grandes laboratórios, empresas individuais, secretarias estaduais,e até mesmo instituições públicas como a EMBRAPA (empresa de pesquisa vinculada ao Ministério da agricultura, pecuária e abastecimento) que se amparam na circulação do capital, ao mesmo tempo e nomeadamente por um regime de verdade que se auto determina como racional, em contraposição ao que entende como uma tecnologia primitiva representada pela agricultura de subsistência, itinerante e rudimentar, como a indígena.

Os arrozeiros se concentravam ao redor dos rios, que são lugares sagrados para as comunidades. Afirma Ana Paula Souto Maior, assessora jurídica do Instituto Sócio Ambiental (ISA), que, contrastando com o modelo de organização comunitária e de partilha da terra que prevalece entre os indígenas, os arrozeiros (que nem posseiros podem ser chamados, pois juridicamente não se pode ter a posse de uma terra indígena) ostentam um modelo feudal de propriedade, usando-a contra tudo e todos, destruindo bens públicos e o meio- ambiente.

Adverte o antropólogo Paulo Santilli que o Estado já saldou cerca de R \$ 12 milhões de reais de indenização aos que, de boa-fé, permaneciam na terra demarcada antes de se concluir a demarcação, e que este valor foi rateado entre pelo menos 190 pessoas. Restaram apenas meia dúzia de invasores, que ingressaram na terra após a demarcação, e que, portanto, não estavam de boa-fé. Joênia Wapixana narra que os rizicultores que lá estavam poluíram o meio-ambiente, empregando agrotóxicos em suas plantações, ocasionando sérios transtornos ao modo

De acordo com José Carlos Moreira da Silva Filho ${ }^{3}$, a advogada Joênia Wapixana, em sua sustentação oral perante o Supremo Tribunal Federal ${ }^{4}$, abordou, primeiramente, alguns elementos importantes sobre a terra cuja demarcação defendia. Afirma ser uma região de, mais ou menos, 1 milhão e 600 mil hectares, correspondente a $8 \%$ do território do Estado de Roraima, que conta com 194 comunidades das etnias Makuxi, Wapixana, Taurepang, Patamona e Ingarikó. São, ao todo, 19.000 habitantes.

O que muitos não sabem é que essas 194 comunidades de povos indígenas produzem toneladas de alimentos (agricultura e pecuária), observa o advogado Paulo Guimarães, no

\footnotetext{
3 Doutor em Direito das Relações Sociais pela Universidade Federal do Paraná, fez uma resenha do Seminário Povos Indígenas, Estado e Soberania Nacional, que foi realizado no dia 28 de maio de 2008, das 09:30h até às 13:30h, no Auditório Dois Candangos, localizado na Faculdade de Educação da Universidade de Brasília, organizado pelo Fórum de Defesa dos Direitos Indígenas (FDDI) e pelo Observatório da Constituição e da Democracia - C\&D (Grupo de Pesquisa "Sociedade, Tempo e Direito" do PPGD da UnB), disponível em http://www.unisinos.br/blogs/ppg-direito/files/2008/06/resenha-doseminario-povos-indigenas-estado-e- soberania-nacional.pdf acessado em 14/06/2015.

4 Supremo Tribunal Federal - http://www.stf.jus.br/portal/cms/verNoticiaDetalhe.asp?idConteudo=118355\&caixaBusca=N acessado em 14/06/2015.
} 
livro Makunaíma Grita (2009). O desenvolvimento dessa produção, aliás, volta-se, sobretudo, para o abastecimento dos indígenas e do próprio Estado de Roraima. O foco principal é o mercado interno, não o agronegócio ou a exportação, como é o caso dos rizicultores. Além disso, como lembra Joênia Wapixana, na população indígena existem 400 agentes de saúde, professores, estudantes universitários muitos na Universidade Federal de Roraima, e pessoas que, de um modo geral, vivem em uma organização comunitária, solidária e que celebra sua cultura e a de seus antepassados.

Ana Paula Souto Maior assessora jurídica do Instituto Socioambiental - ISA (que durante os anos 90 trabalhou na demarcação de terras indígenas, inclusive na da Serra Raposa do Sol), afirma que os índios da Raposa Serra do Sol são um exemplo de partilha coletiva e solidariedade na terra ${ }^{5}$.

Joênia Wapixana, afirma, em sua sustentação oral, que as comunidades indígenas possuem um plano para recuperar aquelas terras, mas de acordo com a sua cultura, e não com o modelo econômico imposto. Aliás, de modo quase unânime, os painelistas notaram que dividir toda a extensão territorial da terra Raposa Serra do Sol entre os 6 rizicultores que por lá protestam ou até mesmo com outros produtores rurais irá trazer muito menos benefícios à sociedade. A cultura indígena, em seu modo de organização, na proteção que faz do meioambiente, não utilizando agrotóxicos, respeitando a floresta, mas não deixando de produzir alimentos, buscando formação técnica para lidar melhor com os problemas de sua gente, é algo por demais valioso para ser trocado por um modelo econômico predatório, voltado para interesses privados e muito mais propenso à internacionalização do que as tribos indígenas (SILVA FILHO, José Carlos, resenha do relatório do Seminário Povos Indígenas, Estado e Soberania Nacional).

Ressaltou, ainda, o antropólogo Stephen Baines, no mesmo seminário, que a densidade populacional de não-índios em boa parte do território de Roraima que não é demarcado é menor do que a dos indígenas em suas terras. A terra Raposa Serra do Sol equivale a $8 \%$ do território do Estado. Somando-se todas as reservas indígenas existentes no Estado, tem-se um território equivalente a 44\%. O território que sobra é do tamanho do Estado de Pernambuco. Lembra ainda o antropólogo, citando o livro "Indigenismo e Territorialização: poderes, rotinas e saberes coloniais no Brasil", organizado por João Pacheco de Oliveira, que, em comparação com os latifúndios, as terras indígenas demarcadas consistem em $18 \%$.

\footnotetext{
${ }^{5}$ Resenha do Seminário dos Povos indígenas. Disponível em:http://www.unisinos.br/blogs/ppg-direito/files/2008/06/resenhado-seminario-povos-indigenas-estado-e-soberania-nacional.pdf acessado em 14/06/2015.
} 


\section{O DIREITO AO DESENVOLVIMENTO SUSTENTÁVEL DAS COMUNIDADES INDÍGENAS}

Em relação ao território que hoje corresponde ao nosso país, a professora Elza Nadai $^{6}$ afirma que, quase 03 milhões de pessoas que ocupavam esparsa, mas totalmente o território, desde as densas florestas amazônicas até as planícies litorâneas e o cerrado, não resta hoje, segundo os mais otimistas, mais que 260 mil, o que representa menos de $0,2 \%$ da população brasileira. Nota-se, ainda, que a quase totalidade não ocupa mais o seu hábitat de origem; 74\% concentra-se na Amazônia (NADAI, 1995).

Ainda de acordo com a professora, as comunidades indígenas, porém, não se limitaram a assistir, passivamente, a conquista da terra pelos portugueses. Ao contrário, foram inimigos duros e terríveis, lutando ardosamente contra seus opressores, defendendo suas terras e liberdade (NADAI, 1995). O primeiro encontro indígena da América do Sul foi realizado em San Bernardino, Paraguai, em outubro de 1974, que reuniu representantes do Brasil, Argentina, Colômbia, Equador, Canadá. E.U.A, Paraguai e Venezuela. Nesse encontro, foi revelada a tomada de consciência pelas nações indígenas de toda a exploração e dominação, além do extermínio, que o europeu praticou ao conquistar o continente americano, é o que podemos extrair desse texto (NADAI,1995, p.7):

Somos o povo índio. Somos uma personalidade com consciência de raça, herdeiros e
executores dos valores culturais dos nossos milenares povos da América,
independentemente de nossa cidadania em cada Estado. (...) Sustentamos que deve-
se ensinar a história começando pela autêntica história das culturas nativas, para
contribuir, assim, para a criação da consciência americana. O respeito, surgido do
conhecimento dos heróis e mártires da história de nossas nações, permitirá um
entendimento maior ente os homens que habitamos essas terras.

Segundo Elza Nadai (1995), são os próprios índios que devem identificar os seus iguais, isto é, pertencentes a comunidades indígenas. Surgiu, então, entre representantes de povos indígenas distintos, a consciência de uma identidade comum, supratribal, enquanto minorias étnicas incorporadas à sociedade brasileira, o que faz com que as comunidades indígenas se considerem distintas da sociedade nacional é a consciência de sua continuidade histórica com sociedades pré-colombianas. Ademais, quando um grupo se auto identifica como indígena, normalmente está presente a solidariedade em meio a seus membros, no sentido da conservação da respectiva identidade.

\footnotetext{
${ }^{6}$ Mestre e Dout ora em História Social pela USP; Livre docente em Educação pela USP; Professora Titular da Faculdade de Educação da USP.
} 
Afirma Pedro Abramovay (2009), que os índios brasileiros difundem-se em 220 comunidades, que falam uma média de 170 línguas diferentes. Metade dessas comunidades tem menos de 50 (cinqüenta) indivíduos, e apenas 3 (três) dessas comunidades têm mais de 20 mil indígenas. A maior parte da população indígena brasileira está concentrada nas regiões Norte e Centro-Oeste.

Segundo Girolamo Domenico Treccani, (2014, p.162), desde o começo do processo de ocupação européia nas terras da Amazônia, os sucessivos governos não levaram em consideração as populações nativas, nem, posteriormente, os moradores locais, fruto da miscigenação entre nativos, portugueses e negros. Analisando a história, pode-se constatar a "invisibilidade" das populações tradicionais, isto é, a falta de política públicas específicas em seu favor. Além da escravidão dos índios e dos negros, a região assistiu ao saque sistemático de suas riquezas naturais que deu origem aos diferentes ciclos econômicos, e completa; (TRECCANI, 2014, p.162):

\begin{abstract}
"se nos primeiros cinco séculos foi favorecido o latifúndio escravocrata, nas ultimas cinco décadas foram privilegiadas: a) as empresas agropecuárias (com a farta e muito pouco fiscalizada política de concessão de incentivos fiscais que favoreceu a grilagemde terras públicas, a degradação ambiental e fomentou os conflitos de terra, fazendo do Estado do Pará "o campeão de conflitos e assassinatos"); b) as madeireiras (com uma exploração em sua grande parte ilegal); c) os grandes projetos industriais e de infraestrutura (que causam o despejo de milhares de famílias) e d) as mineradoras".
\end{abstract}

TRECCANI (2014) enfatiza que nas ultimas cinco décadas, com o total apoio do Estado brasileiro, o capital avançou sempre mais sobre as últimas fronteiras naturais amazônicas disputando território com populações indígenas, quilombolas e demais populações tradicionais e locais, transformando as terras, floresta, água, solo e subsolo em "mercadoria" a ser leiloada na perversa dinâmica das "leis do mercado", em que a exploração indiscriminada da natureza e da própria vida humana viraram "oportunidade de negócio", destruição e conservação que passam a ter preço.

Essa política tem como trágica conseqüência transformas a região amazônica naquela que, em 2012, concentra 97\% da área em conflito no Brasil. Somando-se os conflitos envolvendo os diferentes grupos sociais, percebe-se como em $60 \%$ dos casos as vítimas são grupos cujos territórios estão à margem do mercado de terras. (TRECCANI, 2014 pp. 162163).

Paulo Santilli (2009), afirma que só na Amazônia, contam-se 60 \% (sessenta por cento) da população indígena e $98 \%$ (noventa e oito por cento) das terras indígenas no Brasil. A razão dessa concentração é porque os procedimentos administrativos de demarcação nessas 
áreas podem ser feitos com menos custo político e financeiro que em outras localidades mais demograficamente ocupadas do país. Outro ponto favorável é a cooperação internacional. Desde a ECO92, foi constituído um fundo pelos sete países mais ricos, para preservação das florestas tropicais e para os procedimentos administrativos de demarcação na área amazônica.

Os grupos indígenas encontram-se, quase sempre, em situação de vulnerabilidade, seja do ponto de vista cultural, seja sob o viés econômico e social. A relação e o intercâmbio com o mundo dito civilizado, seja por métodos de assimilação ou de integração, normalmente acomoda os índios nas camadas mais baixas do estrato social, sendo raro que esses grupos alcancem uma situação econômica e social, minimamente, aceitável. Tornam-se, assim, excluídos.

No Brasil, esse acontecimento foi, vastamente, estudado por Darcy Ribeiro, quando abordou o processo de transfiguração étnica, o qual dá origem ao índio genérico, comprovando, de forma irrefutável, a vulnerabilidade indígena (RIBEIRO, 1996), que pode derivar, ainda, de vários outros aspectos, como, por exemplo, a suscetibilidade em relação às doenças, o preconceito e a discriminação por parte da sociedade dominante, e a perda das suas terras tradicionais para o agronegócio. Por todas essas distinções, pode-se assegurar que as comunidades indígenas compõem uma minoria (PINTO FERREIRA, 1995 p. 445) e na condição de minorias que são, encontram-se na categoria de titulares de um direito ao desenvolvimento próprio, o qual deve ter como preocupação não só a efetivação da igualdade sob o ponto de vista da justiça distributiva, mas, também, com o reconhecimento das identidades.

Entretanto, quando estudamos direito ao desenvolvimento dos povos, em decorrência da liberdade conferida às pessoas e às suas coletividades, é natural a existência de distintas percepções e experiências, pois, não é admissível um único modelo de desenvolvimento (PERRONE-MOISÉS, 1999, p. 190).

Nessa mesma linha, é o pensamento de Celso Furtado na acepção de que é muito difícil perceber o desenvolvimento como fenômeno de validade universal, aspiração que teria o mesmo fundamento da tentativa de erguer uma escala de valores que servisse de padrão único para todas as sociedades. Ressaltou o autor, ainda, que a quase totalidade das sociedades contemporâneas atribui prioridade à alta disponibilidade de um conjunto de bens materiais, cujo acesso se embaraça com a figura moderna de vida (FURTADO, 2000. p.107). 
A partir do momento em que se chegou à conclusão de que o desenvolvimento não deveria ser mero sinônimo de industrialização da sociedade, buscaram-se modelos alternativos, que passaram a considerar o termo desenvolvimento, a noção de desenvolvimento sustentável. Nesse contexto, a adoção de propostas e modelos específicos de desenvolvimento sustentável, voltados para as minorias étnicas, notadamente para os grupos indígenas, ganhou alento, principalmente a partir dos anos 70, quando começou a nascer um novo indigenismo, com base na autonomia e na defesa da identidade cultural, cedendo as antigas premissas assimilacionistas (MARTINEZ, 2005). Esse movimento é objeto de estudo pela antropologia, em que recebe a qualificação de etnodesenvolvimento (BARROSOHOFFMANN, 2002, pp.29-31).

O etnodesenvolvimento é uma alternativa à concepção tradicional de desenvolvimento e se inspira em valores como a igualdade e a cidadania, buscando a inclusão plena de setores que se encontram à margem de produção e do usufruto dos resultados do desenvolvimento, o qual passa a ser restrito e submisso a imperativos econômicos. Além disso, uma das balizas do paradigma do desenvolvimento alternativo é o deslocamento do poder dos projetos de desenvolvimento econômico que são realizados a partir de cima (top- down development) pelo modelo de desenvolvimento de base (botton-up development), dos quais os sujeitos coletivos da sociedade civil, passaram a ser considerados sujeitos do desenvolvimento, e não meros objetos deles (SANTOS 2002 pp.46-47).

Para Stavenhagen (1985), o etnodesenvolvimento é um processo dinâmico e criativo que libera energias coletivas para o desenvolvimento das minorias, pois pondera as suas peculiaridades ao incluir o fator étnico nas questões desenvolvimentistas, contestando, frontalmente o modelo clássico de desenvolvimento, que deriva em etnocídio, abrangendo-se como uma política de extermínio da identidade cultural de um grupo étnico.

Conforme Boaventura de Souza Santos (2003), todas as culturas são relativas e pretendem assegurar que seus valores e preocupações próprias sejam válidos em todos os contextos possíveis.

Além disso, é preciso anotar que, de acordo com Pierre Clastres, (2004 pp. 178-179) no que concerne à economia de subsistência dos grupos tradicionais, a percepção é a de que a economia primitiva é uma economia de miséria, o que é um ledo engano, visto que, para ele, é justamente o contrário, uma vez que a sociedade tida como primitiva pode ser até mesmo apontada como a primeira sociedade de abundância, bastando observar que ela utiliza os estoques da própria natureza (CLASTRES, 2004, pp.178-179). Isso implica em dizer que, até mesmo 
o estudo de grupos indígenas, deve considerar o seu próprio modo de compreender a economia e o desenvolvimento que lhe é peculiar.

Deste modo, as comunidades indígenas têm o direito de pensar o desenvolvimento de modo diferente do padrão, pois é indispensável reconhecer que esse desenvolvimento seja visto a partir de outros paradigmas que professem a qualidade de vida, o bem-estar e a felicidade.

Trata-se, assim, de garantir a liberdade dos grupos étnicos indígenas de viver e de buscar o seu bem-estar e a sua felicidade, segundo seus próprios padrões de necessidades básicas e suas respectivas escala de valores, já observada na concepção de Amartya Sen será respeitado o direito à diferença.

Ressalte-se que, um aspecto importante do etnodesenvolvimento é a necessidade de diálogo constante entre as etnias envolvidas. Esse diálogo é importante não só para solidificar a aceitação da visão indígena alternativa de desenvolvimento, mas, também, para guiar as políticas públicas que digam respeito ao desenvolvimento indígena.

Segundo Moreira \& Fonseca (2010) o Desenvolvimento em sua plenitude só pode ser concebido a partir de uma ótica que inclua tem seu conceito o desenvolvimento social, econômico e ambiental. Porém, os padrões de desenvolvimentos vigentes têm privilegiado o aspecto econômico em detrimento dos aspectos socioambientais e é isto que permite a instauração do conflito não entre meio ambiente e desenvolvimento, mais sim entre o desenvolvimento social ambiental e o modelo de crescimento econômico.

Daí a necessidade política de criação do conceito de Desenvolvimento Sustentável, que na verdade nada mais é do que uma lembrança didática e argumentativa de que desenvolvimento só existe quando estão presentes a proteção do meio ambiente e a equidade social, reequilibrando os aspectos múltiplos que compõem o conceito de desenvolvimento. (MOREIRA \& FONSECA, 2010 p.246)

De acordo com Sachs (2008), o desenvolvimento é distinto do crescimento econômico, na medida em que os objetivos do desenvolvimento vão bem além da mera multiplicação da riqueza material. Para ele, o crescimento é uma condição necessária, mas de forma alguma suficiente, para se alcançar a meta de uma vida melhor, mais feliz e mais completa para todos.

Nesse sentido, o desenvolvimento abarca, além da questão do crescimento, a dimensão social, e envolve temas como democracia, justiça social e autonomia estatal (WOLKMER, 2005, p.63). O desenvolvimento, deste modo, deve adotar uma abordagem baseada nos direitos humanos. 
Flávia Piovesan (2010) ensina que o direito ao desenvolvimento requer a ruptura da visão tradicional a inspirar a arquitetura protetiva internacional, na qual as violações de direitos humanos apontam, de um lado, ao Estado como violador e, de outro, ao indivíduo considerado como vítima. No entanto, para a autora, ao compreender tanto uma dimensão

nacional como uma dimensão internacional, o direito ao desenvolvimento tem como violador não apenas o estado e como vítima não apenas o indivíduo, mas comunidades e grupos. Vale dizer que o direito ao desenvolvimento em sua essência se traduz no direito a um ambiente nacional e internacional que assegure aos indivíduos e aos povos o exercício de seus direitos humanos básicos, bem como de suas liberdades fundamentais.

A abordagem de Amartya $\operatorname{Sen}^{7}$ sobre o desenvolvimento foi crucial, tanto na formulação como na evolução conceitual do desenvolvimento humano, como também na participação efetiva na criação do Índice de Desenvolvimento Humano - $\mathrm{IDH}^{8}$. O pensamento do economista entende o desenvolvimento humano como um processo de expansão das liberdades reais que as pessoas desfrutam. (SEN, 2000, p. 17). Desenvolver-se significa abolir os vários tipos de reservas que impedem as pessoas de realizarem livremente suas escolhas e que lhes bloqueiam as oportunidades de exercício de sua ação racional.

Quando as pessoas têm oportunidades apropriadas, tornam-se capazes de harmonizarse com seu próprio destino. de igual modo, quando são detentoras de maior liberdade, as pessoas aumentam o seu potencial de cuidar de si mesmas e de influenciar o mundo, operando como agentes dessas duas questões centrais do processo de desenvolvimento (SEN, 2000, p.33).

Partindo das ideias de Amartya Sen (2000), o PNUD ${ }^{9}$ começou a trabalhar com a noção de desenvolvimento humano, editando o primeiro relatório em 199010 .

De acordo com o relatório, a adoção do desenvolvimento humano deriva do fato de que a verdadeira riqueza de uma nação são as pessoas, e que, por isso, a finalidade básica do desenvolvimento é criar um ambiente apropriado para que os seres humanos gozem de uma vida longa e saudável. Desenvolvimento, dessa forma, constitui tanto o processo de ampliação das oportunidades dos indivíduos, como o nível de bem-estar que eles alcançaram.

Desta maneira, o desenvolvimento que tenha como centro a pessoa humana, e que alcance a cadeia produtiva, gerando a distribuição de riqueza, o bem estar social, as necessidades humanas básicas, o que se deve buscar e que pauta o presente trabalho.

\footnotetext{
7 Amartya Sen ganhou o prêmio Nobel de economia em 1998.

8 Sakiko Fukuda-Parr fez uma análise do papel de Amartya Sen na concepção de desenvolvimento humano e na criação do IDH. Disponível em http://www .pnu d.org.br/hdr/arquivos/R D H globais/hdr2004-portu guese.pdf, acesso em 12/12/14.

9 O Programa das Nações Unidas para o Desenvolvimento (PNUD) é o órgão da Organização das Nações Unidas(ONU)quetem por mandato promover o desenvolvimento e eliminar a pobreza no mundo. Entre outras atividades, o PNUD produz relatórios e estudos sobre o desenvolvimento humano sustentável e as condições de vida das populações, bem como executa projetos que contribuam para melhorar essas condições de vida, nos 166 países onde possui representação. É conhecido porelaboraroÍndice de Desenvolvimento Humano (IDH), bem como por ser o organismo internacional que coordena o trabalho das demais agências, fundose programas das Nações Unidas - conjuntamente conhecidas como Sistema ONU - nos países onde está presente. Relatório disponível emhttp://www.pnud.org.br/hdr/arquivos/RDHglobais/hdr2004-portuguese.pdf, acessado em 18/12/14.
} 
A dimensão individual do direito ao desenvolvimento não afasta a possibilidade de ser adotada uma dimensão coletiva desse mesmo direito (SÁNHEZ, 2005.p.p 194-198).

A inclinação natural da pessoa humana é a vida em grupo. $O$ ser humano não pode ser dissociado da comunidade em que vive, nem, tampouco, das consequências sociais, culturais, econômicas e políticas dessa convivência. Para a completa realização do individuo é necessário acatar as demandas coletivas. Portanto, atende-se à coletividade como objeto único de cada um dos seres humanos que a compõem. A dimensão individual, dessa forma, permanecerá sempre presente, ainda que de maneira subjacente à dimensão coletiva.

A dimensão coletiva foi reforçada com a afirmação da unidade, indivisibilidade e interdependência dos direitos humanos, que têm como um dos seus marcos, a Conferência de Direitos Humanos de Viena, de 1993, introduzindo, no mesmo plano, os direitos individuais e os direitos difusos e coletivos. Até mesmo as futuras gerações podem ser abarcadas como titulares do direito ao desenvolvimento. (SÁNHEZ, 2005. pp.193-194).

A Constituição da República de 1988 garantiu o desenvolvimentista regional e temas correspondentes, como o planejamento, notadamente quando se considera a estrutura adotada para o estado Federal o qual, restaurado, passou a ter como paradigma o federalismo cooperativo (BONAVIDES, 1996, pp.337-506).

Gilberto Bercovici (2003) explana que as políticas de desenvolvimento regional devem ser elaboradas e implantadas, a partir dos marcos do sistema federal instituído, sob a coordenação e cooperação da União e das entidades federadas. Segundo o autor, a construção de um estado Social tem como pressupostos a igualdade e a solidariedade, que geram obrigações para a União e entes federados, cuja atenção deve ter como objetivo a igualação das condições sociais ou necessidades básicas de toda a população, ou seja, a homogeneização social . Surge, segundo o autor, o impedimento de discriminação territorial, conteúdo essencial da igualdade em sua nova dimensão, brotada do federalismo cooperativo constitucionalmente previsto. Ainda conforme o autor, o princípio da igualação das condições sociais é um direito dos cidadãos das regiões menos desenvolvidas, que podem exigir do Estado, como sujeito passivo, que sejam tomadas medidas para garantir a mesma qualidade dos serviços públicos essenciais aos cidadãos das regiões mais desenvolvidas.

A existência de contrastes intergrupais internos mesmo no âmbito dos países mais ricos foi notada por Amartya Sen, que os considera um aspecto relevante da concepção de desenvolvimento e subdesenvolvimento (SEN, 2000, p.20).

O desenvolvimento admite várias concepções ideológicas, que vão desde a ideia de puro crescimento econômico até a noção de desenvolvimento humano, passando, ainda, por 
variações que dão ensejo a expressões, como desenvolvimento social, político, ambiental, nacional, regional, equilibrado e sustentável, dentre muitos outros.

Apesar de várias possibilidades, há um fator comum a todas as concepções, por mais distintas que sejam elas, que é o fato de serem construídas a partir de um mesmo paradigma: o padrão de pensamento das sociedades ditas civilizadas. Nesse padrão, deparamos-nos com diferentes visões de mundo, todavia, todas elas consideram, em maior ou menor grau, fatores como crescimento, progresso, Direito, emprego, consumo, política, participação, investimento, democracia, como valores, precisões ou ferramentas de bem estar e felicidade. Todos os enfoques sobre desenvolvimento avaliam esses e outros aspectos, conjugando-os e escalonando-os, em maior ou menor grau de importância e preferência, a partir do que decorrem as diferentes ideologias existentes.

É possível, deste modo, identificar um direito ao desenvolvimento próprio de coletividades internas, pertencentes a regiões nas quais o desenvolvimento é mais deficiente. Aqueles que compõem essas coletividades têm em conjunto com as pessoas das demais regiões brasileiras, direito ao desenvolvimento geral.

Assim, é imprescindível reconhecer que o direito ao desenvolvimento pode - e deve - atender, de maneira peculiar os grupos mais vulneráveis. Normalmente, há empecilhos pelos Estados e pela população majoritária, que podem se sentir ameaçados pelo reconhecimento de direitos coletivos internos.

A partir dessas premissas, dentre as coletividades que podem ser titulares do direito ao desenvolvimento merecem atenção especial, para fins deste artigo, os grupos indígenas, como minoria, pois carecem de medidas específicas de proteção, além dos direitos humanos reconhecidos a todas as pessoas.

No ano de 1.977, Francesco Capotorti, relator especial de um estudo que tinha por objeto os direitos conferidos pelo artigo 27 do Pacto Internacional sobre Direitos Civis e Políticos, ofereceu uma definição de minoria que, até hoje,é bastante empregada. Para Caportoti (1977 pp. $1-7)^{11}$ :

minoria deve ser entendida como um grupo, numericamente inferior ao restante da população de um estado, em uma posição não dominante, cujos membros, sendo nacionais do Estado, possuem características étnicas, religiosas ou lingüísticas que os diferem do resto da população e demonstram ao menos, implicitamente, um senso de solidariedade no sentido da preservação da cultura, tradição, religião ou língua.

Adotando como parâmetro o Pacto Internacional de Direitos Civis e Políticos de 1966, e a Declaração sobre os Direitos das Pessoas Pertencentes a Minorias Nacionais ou

\footnotetext{
11 Minorias Étnicas, Lingüísticas e Religiosas Disponível em: http://w w w.d hnet.o rg.b r/dado s/cursos/d h/br/pb/dh paraiba/5/mino rias.h tml, acessado em 08/07/2015.
} 
Étnicas, Religiosas e Lingüísticas, de 1992, podem ser considerados elementos diferenciadores a etnia, a religião e a língua, o que dá ensejo ao aparecimento das minorias étnicas, religiosas e linguísticas ${ }^{12}$. Compreende-se assim, que o elemento diferenciador atrelase a dados culturais, que distinguem certas coletividades do todo social. Deste modo, podemos falar em minorias culturais. Essa identidade cultural é o cerne da minoria, a qual, justamente por isso, carece de proteção coletiva de seus traços característicos, sem o que não poderá falar em plena concretização da dignidade de cada um dos seres humanos que a compõem (ANJOS FILHO, Robério, 2008 p.361).

Um estudo sobre a implementação do direito ao desenvolvimento, realizado por Arjun Sengputa em 1999, na qualidade de perito independente sobre o direito ao desenvolvimento da Comissão de Direitos Humanos das Nações Unidas, defendeu, invocando a teoria da justiça de John Raws, que uma das vantagens de empregar uma abordagem de direitos humanos em relação ao desenvolvimento é a probabilidade de priorizar aqueles que se encontram mais atrasados quanto ao gozo dos direitos, determinando que sejam adotadas medidas positivas em seu nome, o que constitui defender os mais pobres ou os grupos mais vulneráveis da sociedade ${ }^{13}$.

\subsection{O direito ao território indígena e à utilização dos recursos naturais}

$\mathrm{O}$ respeito aos direitos dos povos indígenas em relação à propriedade, ao controle e ao acesso às suas terras tradicionais e aos recursos naturais respectivos constitui uma premissa à fruição de todos os demais direitos, sobretudo considerados a indivisibilidade e a interdependência dos direitos humanos ${ }^{14}$. Isso corrobora a natureza crucial que a questão territorial assume quanto ao desenvolvimento desses povos. Tanto é assim que a questão dos direitos territoriais e da utilização dos recursos naturais tem sido o centro dos movimentos indígenas há muito tempo, e tem, como principal, exemplo a judicialização da Terra Indígena Raposa Serra do Sol

\footnotetext{
12 Há referencia expressa aos elementos étnicos, religiosos e lingüísticos serem integrantes da noção de minoria no Pacto Internacionalde Direitos Civis e Políticos de 1966 e na Declaração Sobre os direitos das Pessoas Pertencentes a Minorias Nacionais Étnicas, Religiosase Lingǘrticas de 1992, além nas propostas da ONU, formuladas em 1950,1977,1983 e 1985.

Prof. Arjun K. Sengupta, who was appointed in 1998 by the Commission on Human Rights, has produced three reports, which are available http://www.cdhr.org.in/wp-content/uploads/2015/02/Arjun-Sengupta-Remembrance-tssueCDHR-Bulletin.pdf.Acessado em 20/12-2014.

${ }^{14}$ ST AVENHAGEN, Rodolfo. Informe del Relator especial sobre la situacion de los derechos humanos y las libertades fundamentalesde los indígenas.
} 
No que diz respeito aos índios do nosso continente, a sua condição de povos originários deveria ter ensejado, como conseqüência jurídica, o reconhecimento de seu domínio sobre todas as terras em que habitavam na época da chegada dos europeus ${ }^{15}$.

Deve ficar claro que a terra é vista por eles como seu habitat natural e coletivo, e não como um mero fator econômico, de apropriação individual. Trata-se de uma visão absolutamente distante daquela pertencente à sociedade dominante, vez que abarca uma gestão comunitária da terra e uma relação espiritual com a natureza e os recursos naturais ${ }^{16}$ (DUTERME, 2002, p.4). Para os indígenas, o direito de possuir, ocupar e usar a terra de maneira coletiva é um dado inerente à sua autoconcepção, e, normalmente, esse direito não é conferido ao índio enquanto indivíduo, mas sim à comunidade local, à tribo, ou à nação indígena ${ }^{17}$. A terra constitui, assim, não só fonte de subsistência do índios, como também, sua fonte de existência ${ }^{18}$.

\section{A ECONOMIA NO ESTADO DE RORAIMA ANTES E APÓS A DEMARCAÇÃo DA TERRA DA INDÍGENA RAPOSA SERRA DO SOL}

De acordo com o projeto de levantamento e classificação da cobertura e do uso da terra, realizado pela Secretaria de Planejamento realizado pelo $\mathrm{IBGE}^{19}$, o estado de Roraima apresenta uma alta diversidade fisionômica, sendo, porém a sua maior porção constituída por florestas, vindo, em seguida, as savanas ou campos cerrados que predominam nas partes leste e centro-nordeste, perfazendo um total de $17 \%$ da área do Estado.

No Estado, 90\% dos recursos minerais estão em áreas indígenas, parques florestais e reservas ecológicas. Atualmente esta atividade é realizada ilegalmente na Terra Indígena Raposa Serra do Sol, inclusive com conflitos com mortes ${ }^{20}$, como as ocorridas em 2004, pela disputa de uso da terra entre os índios e os garimpeiros.

\footnotetext{
${ }^{15}$ No Brasil, esse tipo de raciocínio influenciou a formação do instituto do indigenato, segundo o qual, em relação às terras indígenas não há posse a ser legitimada, mas sim um domínio que deve ser reconhecido, em função do direito originário e preliminarmente reservado (MENDES JÚNIOR, João. Os indígenas do Brazil, seus direitos individuais e políticos. Edição fac-similar. São Paulo: Comissão Pro-Índio, 1988, pp. 55-60).

${ }^{17}$ Programa das nações Unidas para o Desenvolvimento. Relatório de Desenvolvimento Humano 2004. Queluz: Mensagem, 2004, p.67.

${ }_{19}^{18} \mathrm{O}$ artigo 13 da convenção 169 da OIT, expressa claramente a relação especial que existe entre os índios e suas terras.

${ }^{19}$ Ministério do Planejamento, Orçamento e Gestão Instituto Brasileiro de Geografia e Estatística - IBGE Diretoria de Geociências Coordenação de Recursos Naturais e Estudos Ambientais - Projeto Levantamento e Classificação da Cobertura e do Uso da Terra no Estado de Roraima - Relatório Técnico, Rio de Janeiro, 2005. Disponivel em: ftp://geoftp.ibge.gov.br/documentos/recursos naturais/manuais tecnicos/usoterra rr.pdf, acessado em 07/07/2015.

${ }^{20}$ A comunidade de Jawari é invadida por tratores e homens armados. Casas são derrubadas e queimadas, e animais são mortos. O índio macuxi Jocivaldo Constantino leva dois tiros, um deles na cabeça, além de ser espancado. O grupo também ataca as comunidades Brilho do Sol, Retiro São José e Homologação. Resultado: 131 pessoas desabrigadas, quatro aldeias destruídas, um índio ferido gravemente e outro desaparecido. Diaponível em: http://ww w.socioambiental.org/inst/esp/raposa/?q=node/216, acessado em 25/06/2015.
} 
Em Roraima, a estrutura fundiária e os modelos de produção mantiveram-se intactos por cerca de dois séculos até a criação do Território e, posteriormente, do Estado. Eram terras situadas no extremo norte do país, onde grandes fazendas de gado, latifúndios, conviviam nas áreas de campos e cerrados com as populações indígenas, que não tinham propriedade legalmente definida. Acrescente-se a esse quadro alguns poucos núcleos garimpeiros isolados nas serras e uma população ribeirinha vivendo da produção extrativista, na zona da floresta e que, muito esparsamente, colocava-se ao longo dos rios, principal meio de comunicação na época, praticamente o único. Fora isso, havia uma vasta área "inexplorada" de mata, onde habitavam outras tantas populações indígenas já contatadas ou ainda não conhecidas do "homem branco".

Vários são os atores que passaram a interagir, formal ou informalmente, nessa estrutura, aparentemente estável, desorganizando-a, em princípio, defendendo ou disputando a posse da terra e o uso dos seus recursos naturais. Correntes migratórias proporcionam a abertura de garimpos, de forma generalizada, desalojando populações indígenas que se encontravam ainda em seu estágio original; reservas indígenas e ambientais foram criadas e a atividade de garimpo foi proibida; muitos assentamentos rurais foram criados e a população que abandonou as glebas se dirigiu a capital Boa Vista, aumentando, consideravelmente, em conjunto com outras populações de outras origens, o percentual da população urbana do Estado.

A reconfiguração da propriedade da terra acontece também via agricultura das grandes e modernas plantações (arroz) que, inclusive, ameaça a hegemonia da produção pecuária. De outro lado, os governos federal e estadual disputam o controle sobre extensas áreas, na questão da federalização das terras, onde os processos de produção são pouco rentáveis, especialmente os da produção extrativista levando ao despovoamento definitivo ao longo de extensos trechos de rio. A intervenção do Estado, desalojando fazendas de gado das áreas indígenas provocou a abertura de novas áreas de mata, em áreas liberadas, para as instalações da rizicultura.

Como exemplo dessa reestruturação fundiária, dados fornecidos pela Centrais Elétricas ELETRONORTE, através de entrevista em outubro de 2004, revelam que 121 fazendas de gado, pertencentes a 101 fazendeiros, foram indenizadas pela empresa como compromisso ajustado com a Fundação Nacional do Índio - FUNAI para a passagem da linha de alta tensão pela Terra Indígena São Marcos, entre Santa Elena, na Venezuela, e a capital do Estado, Boa Vista. Tem-se aqui, com este exemplo, além da reintegração de posse da terra indígena, a mudança de tipo de propriedade da área privada para o poder público federal, e 
mais, a mudança do tipo de posse, da individual para a comunal, em que não mais um fazendeiro decide o destino da propriedade, mas sim toda uma comunidade indígena, com suas regras de decisão.

A área total dos cerrados de Roraima, ao redor de dois milhões de hectares, apresenta condições edafoclimáticas ${ }^{21}$ para a agricultura comercial, voltada para a produção de grãos. Segundo o mesmo relatório, pesquisas diversas realizadas pela EMBRAPA/RORAIMA, relativas ao plantio, à colheita, ao ciclo de desenvolvimento e à produtividade, conclui-se que, devido ao clima favorável, com temperaturas com pouca variação ao longo do ano e uma precipitação adequada o Estado de Roraima apresenta um significativo ganho, se comparado a outras regiões do país. A cultura do arroz irrigado, introduzida recentemente, é praticada em nível comercial e já apresenta um início de industrialização nas áreas de grandes produtores, tornando o Estado autossuficiente neste seguimento, inclusive, gerando excedente exportado para os mercados da Região Norte $^{22}$.

Tem sido observado, nos últimos anos, o interesse de grandes produtores do sul do Brasil pela implantação de culturas comerciais, como a soja, por exemplo, atraídos pela grande oferta de terras, relativamente baratas e com potencial muito grande. Já a agricultura de subsistência, que ocupa maior parte do Estado, é praticada basicamente nas colônias agrícolas existentes na região. Cultiva-se no estado de Roraima arroz de sequeiro em aproximadamente 6.000 ha e 7.000 ha de arroz irrigado, 356 ha de feijão, 5.534 ha de mandioca, 470 ha de melancia, 11.400 ha de milho.

O arroz irrigado com produção em nível comercial no ano de 2004 na região, teve seus maiores produtores nos municípios de Bonfim, Normandia e Pacaraíma, localizados no norte do Estado e as maiores áreas plantadas em Normandia e Pacaraíma. Existia no Estado cerca de 15 empresas formais que se dedicam à comercialização do arroz, tendo como pilares desse cultivo fazendas como Acostumado e Guanabara localizadas na Terra Indígena Raposa Serra do Sol. A área plantada com arroz irrigado era de aproximadamente 7000 ha. Essas fazendas praticavam uma agricultura altamente tecnificada, podendo-se obter até duas safras por ano.

\footnotetext{
21 a expressão «condições edafoclimáticas» refere características definidas através de fatores do meio, tais como o clima, o relevo, a litologia, a temperatura, a humidade do ar, a radiação, o tipo de solo, o vento, a composição atmosférica e a precipitação pluvial. As condições edafoclimáticas são relativas à influência dos solos nos seres vivos, em particular nos organismos do reino vegetal, incluindo o uso da terra pelo homem, a fim de estimular o crescimento das plantas. Disponível em: https://ciberduvidas.iscte-iul.pt/consultorio/perguntas/condicoes-edafoclimaticas/21084, acessado em 07/07/2015.

22 Ministério do Planejamento, Orçamento e Gestão Instituto Brasileiro de Geografia e Estatística - IBGE Diretoria de Geociências Coordenação de Recursos Naturais e Estudos Ambientais - Projeto Levantamento e Classificação da Cobertura e do Uso da Terra no Estado de Roraima - Relatório Técnico, Rio de Janeiro, 2005. p. 32. Disponível em: ftp://geoftp.ibge.gov.br/documentos/recursos naturais/manuais tecnicos/usoterra rr.pdf, acessado em 07/07/2015.
} 
O cultivo do arroz toma impulso principalmente devido ao avanço da fronteira agrícola nos estados do nordeste e norte, comandados por agricultores do sul do país com vasta experiência em culturas graníferas, principalmente o arroz, a soja e o trigo.

Tabela - Quantidade produzida por produtos das lavouras temporárias - série histórica

Produtos das lavouras temporárias

\begin{tabular}{lccc}
\hline Ano & Arroz em casca & Mandioca & Milho em grão \\
1950 & 108 & 2456 & 493 \\
1960 & 1240 & 4601 & 1125 \\
1970 & 1486 & 19733 & 3169 \\
1980 & 17074 & 15985 & $\mathbf{7 0 1 2}$ \\
1990 & 11858 & $\mathbf{2 9 4 5 9}$ & $\mathbf{3 2 7 3}$ \\
2000 & $\mathbf{5 0 8 5 0}$ & $\mathbf{5 8 5 0 0}$ & $\mathbf{1 9 5 0 0}$ \\
2003 & 117720 & $\mathbf{7 4 4 0 0}$ & $\mathbf{2 8 4 4 0}$ \\
$\mathbf{2 0 0 4}$ & 136630 & - & $\mathbf{2 4 0 0 0}$ \\
\hline
\end{tabular}

Fonte: IBGE - Censo Agropecuário, PAM $(1990,2000,2003,2004)^{23}$

- Inexistência do Dado

Ao se avaliar o levantamento da área plantada antes da demarcação da TIRSS, verifica-se que a produção nas terras indígenas foi crescente.

Tabela - Lavoura Temporária- Quantidade produzida $(\mathrm{T})^{24}$

\begin{tabular}{|lc|}
\hline UF e Município $\mathrm{s}$ & Arroz (em casca) \\
\hline Roraima & 117.720 \\
\hline Amajari & 2.300 \\
\hline Alto Alegre & 600 \\
\hline Boa Vista & 1.360 \\
\hline Bonfim & 8.300 \\
\hline Cantá & 2.200 \\
\hline Caroebe & 650 \\
\hline Iracema & 650 \\
\hline Mucajaí & 4.800 \\
\hline Normandia & 44.150 \\
\hline Pacaraima & 51.150 \\
\hline Rorainópolis & 650 \\
\hline São João da Baliza & 190 \\
\hline São Luiz & 140 \\
\hline Uiramutã & 30 \\
\hline
\end{tabular}

Fonte: IBGE PAM 2003

A introdução do arroz irrigado, no estado gerou um elevado aporte de recursos financeiros provenientes dos impostos oriundos desta atividade executada em nível comercial,

\footnotetext{
${ }^{23}$ Instituto Brasileiro de Geografia e Estatística - IBGE - Manual técnico; Disponível em: tpi//g eo ftp.ibge.gov.br/do cumentos/recursos naturais/man uais tecnicos/u soterra rr.pdfacessado em 23/06/15.

${ }^{24}$ Instituto Brasileiro de Geografia e Estatística - IBGE; Disponível em: ftp://g eo ftp.ibge.gov.br/do cu men tos/recursos n atu rais/man uais tecnicos/u soterra rr.pdf, acessado em 30/06/2015
} 
bem como acarretou um aumento significativo do emprego da mão de obra local. Ao se avaliar a evolução do plantio de arroz em uma série histórica, nas últimas décadas, os dados estatísticos mostram que a quantidade produzida de arroz apresenta aumento significativo a partir da década de 80 e que, no período de 2000 a 2004, a quantidade produzida cresce de 50.000 toneladas para 130.000 toneladas.

No entanto, após a demarcação da TIRSS, foi verificado que, de acordo com relatório $^{25}$ do PIB estadual e municipal do estado de Roraima 2010 do Desempenho Econômico do Brasil ,o Produto Interno Bruto - PIB a preços de mercado cresceu em volume no ano de 2010 7,5\% em relação ao ano de 2009. O referido crescimento é o mais elevado desde 1986, que também foi de 7,5\%. No período de 2001 a 2010, o incremento anual médio foi de 3,6\%, acima do registrado na década anterior, 1991-2000, quando o PIB a preços de mercado cresceu, em média, 2,6\%. O aumento do PIB em 2010 resultou no incremento de $6,9 \%$ do valor adicionado bruto a preços básicos e do crescimento de 11,7\% dos impostos, líquidos de subsídios.

O crescimento do volume do valor adicionado bruto da Agropecuária no ano de 2010 decorreu do fato de que várias culturas importantes da lavoura brasileira assinalaram aumento de produção no ano. Influenciada pelas condições climáticas favoráveis, registrando safra recorde de cereais, leguminosas e oleaginosas em 2010 - 149,5 milhões de toneladas cabendo destaque às seguintes culturas: soja (20,2\%); trigo (20,1\%); café (17,6\%); milho (9,4\%); cana-de-açúcar (5,7\%); e laranja (4,1\%). Com exceção da cana-de-açúcar, cuja área plantada teve variação próxima à da sua produção $(5,8 \%)$, todas as demais culturas em destaque no ano de 2010 apontaram ganhos de produtividade.

Neste sentido, verifica-se que a demarcação da TIRSS não foi empecilho para o desenvolvimento do Estado, uma vez que segundo Joênia Batista de Carvalho ${ }^{26}$, ao subir na tribuna para fazer sustentação oral da TIRSS, as terras tradicionais indígenas vão além da casa dos índios, englobando os locais considerados sagrados e destinados à religiosidade e a outras manifestações culturais. Visando rebater o argumento de que a presença dos arrozeiros é essencial para o desenvolvimento da região, a advogada lembrou que os povos da TIRSS têm, sim, atividades econômicas, que, no entanto, não são contabilizadas pelo Estado de Roraima. são mais de 14 milhões de reais em circulação por ano, com a maior criação de gado do Estado, 36.233 cabeças contabilizadas no Projeto Gado pela FUNAI em 2007. E no que diz

\footnotetext{
${ }^{25}$ Produto Interno Bruto dos Municípios de Roraima - IBGE. Disponível em: ftp://ftp.ibge.gov.br/Pib Municipios/2010/pibmunic2010.pdf acessado em 25/05/2015.

${ }^{26}$ Primeira índia a se tornar advogada no Brasil da etnia Wapixana, em sustentação oral no STF.
} 
respeito ao desenvolvimento humano e educacional, a região abriga mais de 300 escolas indígenas, com 485 professores e mais de 5600 alunos.

Além disso, Joênia alertou para os graves prejuízos ambientais provocados pela exploração irracional de produtores não-índios, mencionando a multa aplicada pelo IBAMA em 2008 por impactos ambientais causadas por arrozeiros e questionando o porquê teriam de ser os índios, punidos, tendo a sua terra retalhada.

De acordo com Sen (2010 p. 43), a principal esperança de se obter harmonia no mundo contemporâneo se encontra na pluralidade de nossas identidades, que se cruzam umas com as outras e agem contras as divisões rígidas em torno de uma linha única e endurecida de divisão impenetrável. Nossa humanidade compartilhada é desafiada, brutalmente, quando o confronto é unificado em um só suposto sistema dominante de classificação. A diversidade plural pode ser muito unificadora, de uma forma que um sistema único de divisões predominantes não é.

\section{CONSIDERAÇÕES FINAIS}

Os povos indígenas brasileiros ainda necessitam de proteção especial em face dos impactos negativos que podem advir da ganância do poder econômico, da omissão do Estado e de projetos de desenvolvimento nacional.

Uma forma importante de proteção é o reconhecimento de que são, também, titulares do direito ao desenvolvimento e que este direito, neste contexto, ganha peculiaridades próprias, garantidas pelo ordenamento positivo brasileiro no plano constitucional.

A proteção a esse direito é tão importante que a Constituição da República de 88 consagrou que constituem patrimônio cultural brasileiro os bens de natureza material e imaterial, tomados individualmente ou em conjunto, que sejam portadores de referencia à identidade dos grupos que formam a sociedade brasileira, dentre os quais, incluem-se os índios $^{27}$. Também determinou a proteção dos bens, de qualquer natureza, que digam respeito à ação e à memória desses grupos.

Vale anotar que, as comunidades indígenas são titulares do direito ao desenvolvimento, o qual ganha contornos especiais quando vinculado a elas, tendo em vista as suas especificidades, e muito embora, o direito ao desenvolvimento indígena não tenha sido expressamente mencionado pela Constituição de 1988, o regime e os princípios por ela adotados, bem como os tratados internacionais ratificados pela Republica Federativa do Brasil

27 Artigo 216 da CRFB. 
é parte, permitem concluir no sentido da integração do direito ao desenvolvimento ao direito positivo brasileiro como um direito fundamental.

O desenvolvimento nacional deve considerar a nação como um todo, não apenas a parcela majoritária. É preciso considerar diferentes visões de desenvolvimento pertencentes às múltiplas coletividades humanas que formam, conjuntamente, o estado pluriétnico e pluricultural.

Conclui-se que a demarcação da TIRSS não foi empecilho para o desenvolvimento do Estado de Roraima, uma vez que os povos da TIRSS têm, sim, atividades econômicas, que, no entanto, não são contabilizadas pelo Estado de Roraima. São mais de 14 milhões de reais em circulação por ano, com a maior criação de gado do Estado, 36.233 cabeças, contabilizadas no Projeto Gado pela FUNAI em 2007. Ademais, conforme demonstrado no presente trabalho, o PIB do estado aumentou após a demarcação da TI, e o mais importante, os indígenas promovem seu desenvolvimento sustentável e participam na economia local.

Entretanto, à medida que essas terras são reivindicadas por agentes do sistema produtivo capitalista, o Estado opera no sentido de dar garantia aos direitos indígenas, mas no sentido de fazer valer os direitos dos agentes econômicos, sejam eles personificados na grande lavoura, na pecuária, no extrativismo ou nos megaprojetos de infraestrutura que buscam viabilizar o abastecimento das regiões industriais de matérias primas e recursos energéticos. $\mathrm{O}$ proclamado interesse nacional legitima o desrespeito aos interesses dos povos indígenas. É o que podemos observar dos argumentos utilizados no julgado do Supremo Tribunal Federal, quando do julgado acerca do processo de demarcação das terras indígenas Raposa Serra do Sol. Qualquer que fossem as condicionantes a serem considerados, a primazia restritiva deveria ser dada ao interesse nacional, aspecto que deverá ser estendido a todas as posteriores demarcações de terras indígenas no Brasil.

\section{REFERÊNCIAS BIBLIOGRÁFICAS}

ABRAMOVAY, Pedro. O novo estatuto dos povos indígenas - Inovações. Políticas públicas de proteção e promoção dos povos indígenas. Brasilia-DF. Escola da Advocacia geral da União, 02 de dez.02009. Palestra transmitida pela TV Escola. Disponível em: htpp://www.agu.gov.br/escola. Acesso em 15/01/2015.

ANJOS FILHO, Robério Nunes dos. Minorias e grupos vulneráveis: uma proposta de distinção. In ROCHA, João Carlos de Carvalho. HENRIQUES FILHO, Tarcísio Humberto Parreiras, CAZETA, Úbiratan - coords. Direitos Humanos: Desafios Humanitários Contemporâneos. Belo Horizonte: Del Rey, 2008, p.361 
ARROYO, Leonardo. A carta de Pero Vaz de Caminha. São Paulo, Melhoramentos, 1971. P.63

AZENHA, Gilberto. Etnodesenvolvimento, mercado e mecanismos de fomento: possibilidades de desenvolvimento sustentado para as sociedades indígenas no Brasil. In LIMA, Antonio Carlos de Souza, BARROSO-HOFFMANN, Maria (orgs.) etnodesenvolvimento e Políticas Públicas: bases para uma nova política indigenista. Rio de Janeiro: Contra Capa/LACED, 2002.

BALDI, César Augusto. Direito indígena: Raposa Serra do Sol desafia capacidade dos ministros do STF. In: Consultor jurídico. Disponível em < http://conjur.estadao.com.br/static/text/65756,1 >. Acesso em 23. mai. 2008.

BERCOVICI, Gilberto. Desigualdades Regionais, Estado e Constituição. São Paulo: Max Limonad, 2003.

BONAVIDES, Paulo. A constituição aberta: Temas políticos e constitucionais da atualidade, com ênfase no federalismo das regiões. 2a edição. São Paulo: Malheiros, 1996.

BRASIL. Constituição da República Federativa do Brasil. 24. ed. Brasília: Câmara dos Deputados, Coordenação de Publicações, 2006.

BRITTO, Carlos Ayres. "Voto do ministro relator. 27 de agosto de 2008”. In: Makunaima Grita: Terra Indígena Raposa Serra do Sol e os direitos constitucionais no Brasil. Rio de Janeiro: Beco do Azougue, 2009. Pp. 173-214.

CARVALHO, Joênia Batista de. Org. Makunaíma grita: Terra indígena Raposa Serra do Sol e os direitos constitucionais no Brasil. Rio de Janeiro: Beco do Azougue, 2009.

CASTRO, Luciano. Terra de índio: Projeto anula homologação de reserva indígena. In: Consultor Jurídico. Disponível em $<$ http://conjur.estadao.com.br/static/text/34976,1>. Acesso em 26 mai. 2008.

CLASTRES, Pierre, Arqueologia da Violência: pesquisas de antropologia política. São Paulo: Cosac \& Naify, 2004.

COLOMBO, Cristovão. Diários da descoberta da América: as quatro viagens e o testamento. Tradução de Milton Persson. Porto Alegre: L\&PM, 1998.

COMPARATO, Fábio Konder. A Civilização Capitalista: para compreender o mundo em que vivemos. São Paulo: Saraiva, 2013.

CORDEIRO, A C. C. "Situação atual e perspectivas para a rizicultura no estado de Roraima". In: Anais do II Congresso Brasileiro de arroz irrigado e XXIV Reunião da cultura do arroz irrigado, 20 a 23 de agosto. Porto Alegre, IRGA, 2001. P. 749-750.

CORDEIRO, A. C. C.; MOURO JUNIOR, M. C.; MEDEIROS, R. D. "Análise do agronegócio do arroz irrigado em Roraima: período 191 a 2007." In: Anais do Congresso Brasileiro de Arroz Irrigado, 6.; Reunião da Cultura do Arroz Irrigado, 28., 2007, Porto Alegre. Anais... Porto Alegre: Orium, 2007. p. 719-721. 
CUNHA, Manuela Carneiro da. Os direitos do índio: ensaios e documentos. São Paulo: Editora Brasiliense: 1987.

DALLARI, Dalmo de Abreu. Org. Makunaíma grita: Terra indígena Raposa Serra do Sol e os direitos constitucionais no Brasil. Rio de Janeiro: Beco do Azougue, 2009

DUTERME, Bernard, peuples indigénes et minories ethniques: les conditions sociales de leur reconnaissance. In Alternatives Sud, Editorial, vol. VII, Paris, centre tricontinental, L'Harmattan, 2000-2).

FARAGE, Nádia. As muralhas dos sertões: os povos indígenas no Rio Branco e a colonização. São Paulo, SP : Paz e Terra, 1991.

FARAGE, Nádia \& SANTILLI, Paulo. Org. Makunaíma grita: Terra indígena Raposa Serra do Sol e os direitos constitucionais no Brasil. Rio de Janeiro: Beco do Azougue, 2009.

FURTADO, Celso. Teoria e Política do desenvolvimento econômico. $10^{\circ}$ edição. São Paulo: Paz e Terra, 2000.

LIMA, Daniel. A disputa pela Raposa do Sol. Estadão. Disponível em < http $/ /$ www.estadao.com.br/interatividade/Multimidia/ShowEspeciais!destaque.action?destaqu e.idEspeciais=631>. Acesso em: 23. mai. 2008.

MARTINEZ, Juan Daniel Oliva. La Cooperación Internacional con los Pueblos Indígenas: desarollo y derechos humanos. Madrid: Cideal, 2005.

MORAWSKA VIANNA, Catarina. Seguindo as trilhas do gado e do arroz na Raposa Serra do Sol: conexões transnacionais no embate entre a pecuária indígena e a rizicultura corporativa. Porto Alegre, 2015

MOREIRA, Eliane \& FONSECA, Luciana Costa da. DIREITO, Meio ambiente e desenvolvimento no contexto amazônico. In: DIAS, Jean Carlos; KLAUTAU FILHO, Paulo. Direitos Fundamentais, Teoria do Direito e Sustentabilidade. São Paulo; Método; Belém: CESUPA, 2010 p. 245.

NADAI, Elza \& NEVES Joana. História do Brasil, São Paulo: Editora Saraiva, 1995.

OLIVEIRA, Roberto Cardoso de. Caminhos da Identidade: ensaios sobre etnicidade e multiculturalismo. São Paulo: Editora UNESP, 2006

PERRONE-MOISÉS, Cláudia. Direitos Humanos e Desenvolvimento: a contribuição das Nações Unidas. In AMARAL JÚNIOR, Alberto do, PERRONE-MOISÉS, Cláudia (orgs.). O Cinquentenário da Declaração Universal dos Direitos do Homem. São Paulo: Editora da Universidade de São Paulo, 1999, p. 190.

PIOVESAN, Flávia. Direito ao desenvolvimento - Desafios Contemporâneos. In: PIOVESAN, Flávia; SOARES, Inês Virginia Prado (Coordenadoras). Direito ao Desenvolvimento. Belo Horizonte: Fórum, 2010.

PINTO FERREIRA. Curso de direito constitucional. $7^{\text {a }}$ ed. São Paulo: Saraiva, 1995. RIBEIRO,

Darcy. Os índios e a civilização: a integração das populações indígenas no Brasil moderno. São Paulo: Companhia das Letras, 1996.

RAWLS, Jonh. Justiça como equidade: uma reformulação. São Paulo: Martins Fontes, 2003; 
SACHS, Ignacy. Desenvolvimento: Includente, Sustentável, Sustentado. Rio de Janeiro: Garamond, 2008.

RICUPERO, Rubens; MASSAD, Anselmo; ROVAI, Renato. “Índios e Capitalismo de Faroeste” In: Julia T. Miras [et al]. Makunaima Grita: Terra Indígena Raposa Serra do Sol e os direitos constitucionais no Brasil. Rio de Janeiro: Beco do Azougue, 2009. Pp. 147-152.

RIVIÈRE, Peter. The Forgotten Frontier: Ranchers of Northern Brazil. New York: Holt, Rinehart and Winston. 1972. SAKAZAKI, Roberto T. et al.,- Arroz irrigado em Roraima. Agro@mbiente On-line, vol.2, no 1, jan/jun, Boa Vista, 2008. pp. 69-76

SÁNHEZ, Nicolás Ângulo. El derecho al desarrollo frente a la mundialización del mercado: conceptos, contenido. Objetivos y sujetos. Madrid: IEPALA, 2005.

SEPLAN - Secretaria de Planejamento e Coordenação / Governo de Roraima. I Plano de Desenvolvimento de Roraima, Volume 1. Boa Vista: SEPLAN, 1980.

SANTILLI, Paulo. Terras indígenas. Dimensão Antropológica e histórica. Brasîlia - DF Brasilia -DF. Escola da Advocacia geral da União, 02 de dez.2009. Palestra transmitida pela TV Escola. Disponível em: htpp://www.agu. gov.br/escola. Acesso em 30/03/2015.

, Paulo. As Fronteiras da República. História e política entre os Macuxi no vale do rio Branco. São Paulo: FAPESP e NHII - USP, 1994.

SANTOS, Boaventura de SOUZA, RODRIGUEZ César. Para ampliar o cânone da produção. In SANTOS, Boaventura de SOUZA (org.) Produzir para viver: os caminhos da produção capitalista. Rio de Janeiro: Civilização brasileira, 2002.

- Por uma concepção multicultural de direitos humanos. In SANTOS, Boaventura de SOUZA (org.) reconhecer para libertar: os caminhos do cosmopolitismo multicultural Rio de Janeiro: Civilização brasileira, 2003.

Afrontamento, 1994

Pela mão de Alice: o social e o político na pós-modernidade. Porto: Edições

SAKAZAKI, Roberto T. et al.,- Arroz irrigado em Roraima. Agro@mbiente On-line,vol.2, no 1, jan/jun, Boa Vista, 2008. pp. 69-76.

SEN, Amartya Kumar. Desenvolvimento como liberdade. São Paulo: Companhia das letras, 2000 .

STAVENHAGEN, Rodolfo. Etnodesenvolvimento: uma dimensão ignorada no pensamento desenvolvimentista. In anuário antropológico, $\mathrm{n}^{\circ}$ 84. Rio de Janeiro: Tempo Brasileiro, 1985

TRECCANI, Girolamo Domenico. Populações tradicionais e mineração. In: DIAS, Jean Carlos; GOMES, Marcos Alan de Melo. Direito e Desenvolvimento. São Paulo; Método; 0020Belém: CESUPA, 2014 p. 161

WOLKMER. Antônio Carlos; WOLKMER, Maria de Fátima S. Direitos Humanos e Desenvolvimento. In BARRAL, Welber (org.). Direito e Desenvolvimento: análise da ordem jurídica brasileira sob a ótica do desenvolvimento. São Paulo: Editora Singular, 2005. 